\title{
難 治性の脊椎カリエスの検討
}

\author{
宮崎医科大学整形外科教室 \\ 松本宏一・田島直也 \\ 川野桂一郎・田代宏一 \\ 田辺 龍 樹
}

\section{Investigation of Tuberculous Spondylitis Resistant to Therapy - Report of Two Cases - \\ by}

\author{
Koichi Matsumoto, Naoya Tajima, Keiichiro Kawano, \\ Koichi Tashiro and Ryuji Tabe \\ Department of Orthopedic Surgery, Miyazaki Medical College
}

\begin{abstract}
The cases who twice underwent surgery for tuberculosis of the spine are reported. Both patients received radical surgical treatment and chemotherapy with isoniazid, rifampicin and streptomycin. In the first case spondylitis recurred five months after the first operation. In the second case it recurred one month after. The tubercle bacillus of the first was found to have resistance to rifampicin, para-aminosalicylic acid and streptomycin. That of the second case was found to have resistance to rifampicin, ethanbutal, kanamycin and streptomycin.

Each patient received a second operation. In the first case antituberclous drugs were changed to isoniazid, ethanbutal and kanamycin, and in the second case antituberclous drugs were changed to isoniazid and ethionamide. Both patients have recovered and are doing well with solid fusion noted.
\end{abstract}

\section{は じめに}

脊椎カリエスは近年化学療法の発達と共に着実に減 少しつつあるが, 現在でも脊椎感染症の中で依然とし て重要な疾患であることに変わりはない.

今回再手術を必要とした難治性脊椎カリエスの 2 症 例を経験したので若干の考察を加え報告する．

\section{症例}

症例 $1: 26$ 才, 男性.

主訴: 腰痛.

既往歷：特記すべきことなし。

家族歷：祖父に結核の既応あり.

現病歷：昭和 60 年 5 月より腰痛が出現し,しだいに 増強した. 同年 11 月より体重減少, 微熱 $\left(37^{\circ} \mathrm{C} \sim 38^{\circ} \mathrm{C}\right)$ がみられるようになり, 以後症状が持続していた。昭
和 61 年 7 月脊椎カリエスの疑いにて当科に入院となっ た.

入院時所見：胸腰推椎行部に右凸側弯がみられ, 腰 椎可動域制限が大きく, 第 12 胸椎から第 5 腰椎棘突起 にかけて压痛・吒打痛を認めた。両側膝蓋腱反射抢上 びアキレス腱反射の光進がみられた。

検查成績: 血沈值 $53 \mathrm{~mm} / 1$ 時間, $95 \mathrm{~mm} / 2$ 時間 CRP (H), 赤血球 495 万 $/ \mathrm{mm}^{3}$, 白血球 $6,400 / \mathrm{mm}^{3}$, ツベルクリン反応 強陽性 $\left(\frac{21 \times 23}{56 \times 37}\right)$, 結核菌培養 喀 痰 $(-)$, 胃液 $(+)$.

単純レ線所見：正面像にて第 11,12 胸椎椎間および 第 12 胸椎, 第 1 腰椎椎間の狭小化, 傍脊柱膿瘍像がみ られ，側面像にて同椎間の狭小化および第 $10,11,12$ 胸椎, 第 1 腰椎の椎体破壊像がみられた。胸部レ線像 では右側に胸膜のひきつれがみられた。

断層撮影像：第 10 胸椎下縁上り第 11,12 胸椎，第 
1 腰椎の溶骨像がみられた（図 1 )。

CT : 椎体破壊像, 傍脊柱膿陽像, 腸腰筋腫大像がみ られた。

シンチグラフィー: 骨シンチにて第 6 胸椎より第 4

腰椎まで集積像を認めた。

経過（図 2 ）：昭和 61 年 7 月 17 日手術を施行す。手 術では傍脊柱部および腸腰筋に膿を認め,これを排膿 した。また，病巣椎体も十分に搔爬し，腓骨および腸 骨より採取した骨片を用い前方固定を行った。抗結核 剂は手術一週間前より INH $450 \mathrm{mg} /$ 日, RFP $450 \mathrm{mg}$ / 日，SM $1 \mathrm{~g} \times 2$ 週を投与した。術後ベット上安静とし ていたが，同年 10 月末より $37^{\circ} \mathrm{C} \sim 37.5^{\circ} \mathrm{C}$ の発熱が続 き 11 月初旬より血沈值の六進をみるようになった. 12 月初めに左側腹部腫瘤がみられ, 穿刺にて膿を認めた。
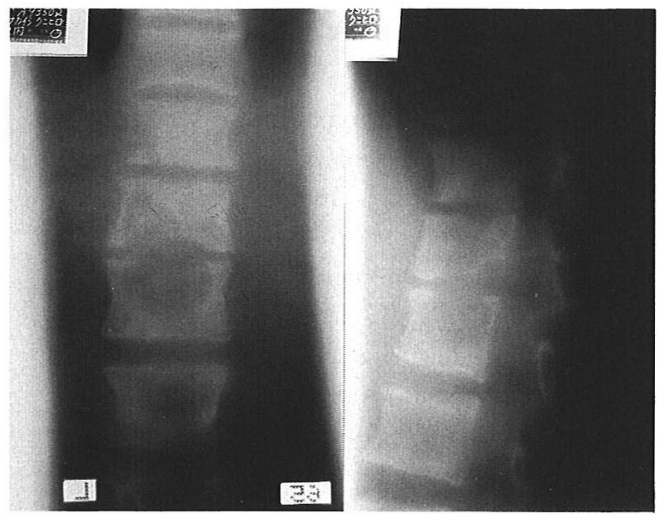

図 1 症例 1 : 術前断層撮影像 $\mathrm{T}_{11,12} \mathrm{~L}_{1}$ 椎体の溶骨像がみられる
CT にても両側腸腰筋の膿湯像がみられた。昭和 62 年 2 月 9 日再手術を施行した（図 3 )。抗結核剂は INH, $\mathrm{EB}, \mathrm{KM}$ に変更した。現在は経過良好であり，コルセ ット装着にて外来通院中である。 症例 $2: 32$ 才, 男性.

主訴: 腰痛。

既往歴： 3 才時に腰椎カリエスに罹患。

家族歴：叔父に結核の既往あり。

現病歴：昭和 61 年 9 月より腰痛が出現した。続いて 右股関節部痛も現われ跛行を呈すようになった。同年 11 月末より $37^{\circ} \mathrm{C}$ 前後の発熱があり，12 月脊椎カリエ スの疑いにて当科に入院となる。

入院時所見：腰椎可動域制限あり。第 $2 ， 3 ， 4$ 腰 椎棘突起に圧痛あり．右単径部にも圧痛を認める。神 経学的には異常所見なし。

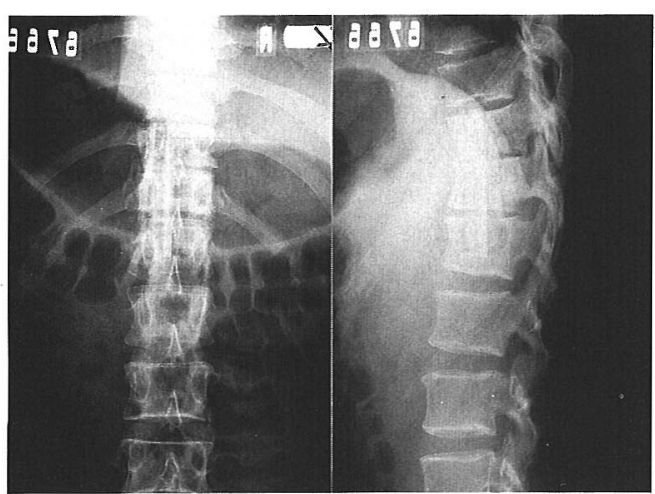

図 3 症例 1 術後 1 力月の単純レ線像

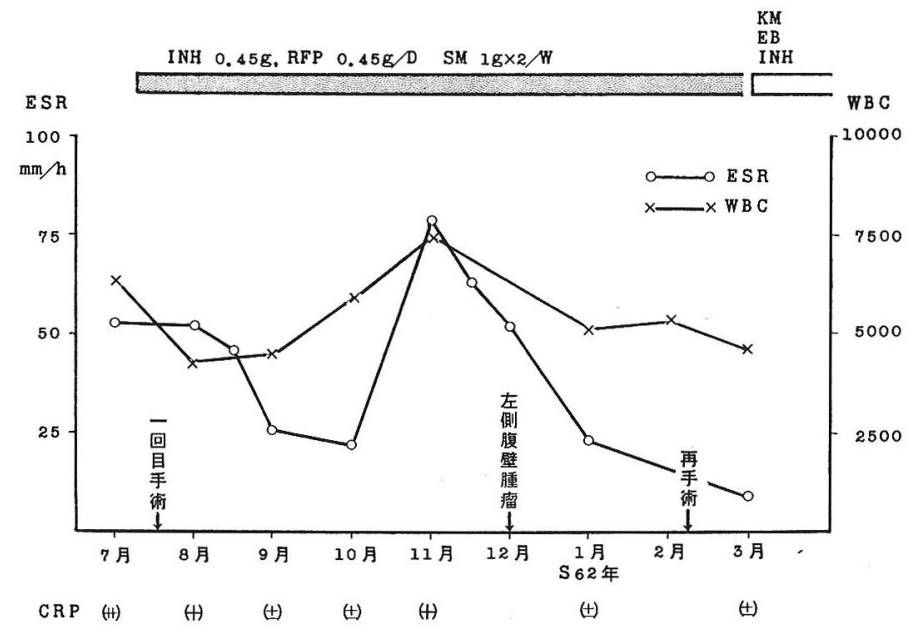

図 2 症例 1 の経過と治療 


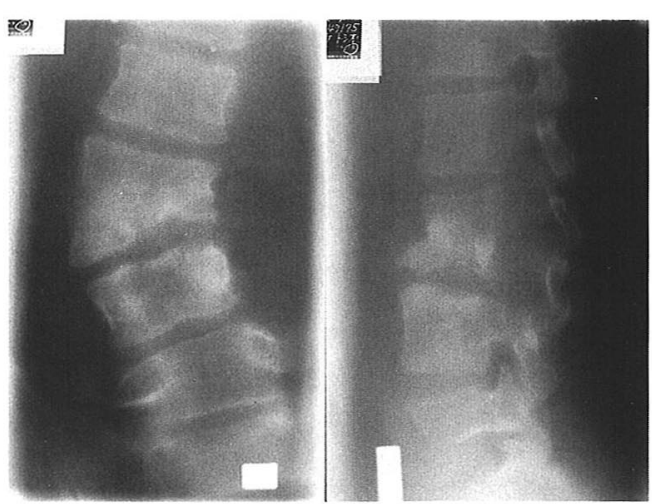

図 4 症例 2 術前断層撮影像

$\mathrm{L}_{2.3}, \mathrm{~L}_{4}$ の椎体の骨破壊像がみられる

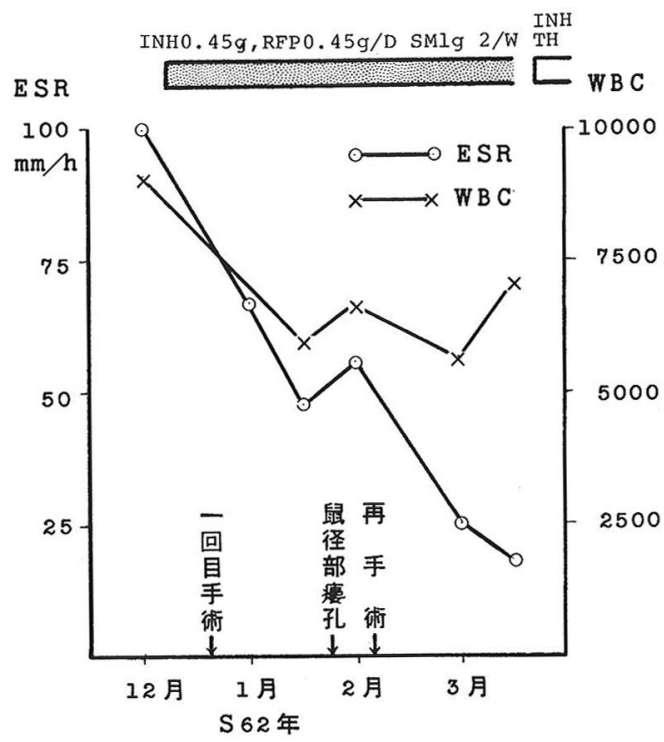

C R P

(II)

(1)

(t)

図 5 症例 2 の経過と治療

検查成績 : 血沈値 $86 \mathrm{~mm} / 1$ 時間, $97 \mathrm{~mm} / 2$ 時間, CRP $(H)$, 赤血球 473 万 $/ \mathrm{mm}^{3}$, 白血球 $9,100 / \mathrm{mm}^{3}$, ツベルクリン反応 強陽性 $\left(\frac{7 \times 8}{50 \times 28}\right)$.

単純レ線所見: 第 2,3 腰椎の癒合がみられ, 第 2 ,

3,4 腰椎の骨破壊像がみられた。胸部レ線像にて両 側肺尖部に陳旧性肺結核を疑わせる異常陰影を認めた。

断層撮影像：第 $2 ， 3 ， 4$ 腰椎椎体の溶骨像がみら れた（図 4 )。

CT : 第 $2 ， 3 ， 4$ 腰椎の骨破壊像および右腸腰筋の 大きな膿瘍像を認めた。
経過（図 5 ）：昭和 61 年 12 月 18 日手術を施行す. 手術では右腸腰筋より約 $500 \mathrm{ml}$ の膿を排出した。病巣 椎体を十分搔爬し，骨移植を行った。抗結核剤は術前 より INH $450 \mathrm{mg} /$ 日, RFP $450 \mathrm{mg} /$ 日, SM $1 \mathrm{~g} \times 2$ / 週を投与していた。翌年 1 月半頃より右単径部に流注 膿瘍と思われる腫瘤を触知するようになり 1 月 21 日自 潰した。 2 月 2 日再手術を施行した。現在は経過良好 であり，抗結核剂は INH, THに変更している。

考察

脊椎カリエスの治療は近年化学療法剤の開発, とく に 1970 年代前半からの Rifampicin の導入と手術療法 の発達により飛躍的進歩をとげた。

それでもなお現在化学療法の骨関節結核への応用の 詳細な研究は必ずしも十分とはいえず, 薬剤使用量お よび使用期間共に肺結核治療に準じている状態であ る ${ }^{1) 31}$. 肺結核に対しわが国で推奨されている標準的な 化学療法は日本結核病学会治療専門委員会の見解 ${ }^{4)} に$ 示されているように INH, RFP を中心としてこれに SM または EB を加える 3 剽併用法である.この中心薬剤で ある INH あるいは RFP に耐性を示す例では当然治療 効果は期待出来ない占.

症例 1 は初回治療例であるが, 初回手術時の膿より 培養した病巣菌の薬剂耐性検査の結果, RFP, PAS, $\mathrm{SM}$ に耐性を示し，再手術後に投与薬剤は INH，EB， $\mathrm{KM}$ に変更した。症例 2 は小児期に春椎カリエスにて 治療を受けた再発例である。病巣菌は INH 以外の多く の主要薬剂に耐性を示し，投与薬剂を INH, TH に変 更した(表 1 )。わが国の場合，主要抗結核剂の末治療 而性の頻度は 1982 年の成績では INH 4.2\%, RFP 1. 3\%, SM 8.8\%, EB 1.1\%, KM 0.5\%となっている2).

表 1 薬 郕 耐 性

\begin{tabular}{c|c|c}
\hline \hline & 症 例 1 & 症 例 2 \\
\hline INH & - & - \\
S M & + & + \\
PAS & + & + \\
K M & - & + \\
T H & - & - \\
C S & + & + \\
RFP & + & - \\
CPM & + & + \\
E B & - & - \\
V M & + & \\
\hline
\end{tabular}

十 耐性あり

一 耐性なし 
一方, 薬剂耐性検査の結果が判明するまでに症例 1 では 6 力月, 症例 2 では 4 力月を要した.このように 脊椎カリエス例では病巣菌培養の陰性例が多いことや 培養陽性例でもその菌の量が少なく間接法にたよるこ とになるため耐性検査の結果を知るまでに数力月を必 要とする，さらに病巣より菌採取を繰り返すことが困 難であるなど，抗結核剤選択を遅らせる原因となり脊 椎カリエスの治療の障害となっている.

今後, 薬剂耐性菌が存在することも考慮に入れて, 薬剤使用法すなわち使用量および使用期間の検討が必 要であり,さらに新しい抗結核剤の開発が望まれる。

\section{ま と め}

1. 再手術を要した難治性脊椎カリエスの 2 症例に ついて報告した。

2. 春椎カリエスの治療において薬剤耐性菌の存在 に十分な注意が必要であり, 今後化学療法剤の使用方 法などについて再検討の必要があると思われる。

\section{参 考 文 献}

1）百町国彦：脊椎カリエスの治療. 日整会誌, $55 ： 1643$ $-1659,1981$.
2）結核療法研究協議会：わが国における薬剤耐性結核菌 感染の実態と対策に関する研究. 昭和 57 年度療研研究 報告書, 1,1983 .

3）田島直也・他：腰椎部炎症. 腰痛その診断と治療のす べて, 227-233, 金原出版, 東京, 1983.

4）日本結核病学会治療委員会：結核化学療法の期間に 関する見解。結核， $55 ： 189,1980$.

5）山本正彦：肺結核。内科, $58: 292-297,1986$.

質 問熊本整形外科病院 栄 輝巳

術前の CT 所見を検討したか両側腸腰筋に病変が伴 っている場合は両側共十分にソウハ廓清しないと十分 でないと思われるが.

解 答宮崎医科大学 松本 宏一

術前 CT にて腸腰筋の膿癔を確認している.両腸腰 筋膿瘍は十分廓清した。

\section{追 加州大学 柴田堅一郎}

われわれも薬剤の感受性のほとんどない症例の手術 例を最近経験しましたが，骨病変部と周囲の軟部組織 の搔爬を十分に行えば良好な結果がえられると考えて おります。 